\title{
HIRARKI
}

Jurnal Ilmiah Manajemen dan Bisnis

http://iournal.upp.ac.id/index.php/Hirarki

\section{PENGARUH PEMILIHAN TATA LETAK PRODUK, HARGA DAN KELENGKAPAN PRODUK TERHADAP KEPUTUSAN PEMBELIAN PADA SWALAYAN "GRACE MART" BANGUN JAYA}

Purwantoro

Manajemen Faculty, University of Pasir Pengaraian

\section{Info Artikel}

Sejarah Artikel:

Diterima 09 Agustus

2019

Disetujui 01 September

2019

Dipublikasikan

03 Juli 2019

Keywords:

Tata letak, Harga, Keputusan Pembelian.

\begin{abstract}
Abstrak
Penelitian ini bertujuan untuk mengetahui pengaruh tata lekat produk, harga dan kelengkapan pruk terhdap keputusan pembelian.Metode pengambilan sampel yang digunakan adalah Accidental Sampling Method. Sampel dalam penelitian ini adalah 100 orang konsumen dari Grace Mart Bangun Jaya. Analisis data secara kuantitatif dan kualitatif. Pengujian hipotesis menggunakan uji t menunjukkan bahwa variabel independen yang diteliti terbukti secara signifikan tidak berpengaruh secara parsial terhadap variabel dependen Keputusan Pembelian. Kemudian dapat diketahui bahwa ketiga variabel independen yang diteliti secara simultan berpengaruh terhadap variabel dependen Keputusan Pembelian. Dari hasil penelitian dapat disimpulkan bahwa variabel tata letak produk, harga dan kelengkapan produk baik secara parsial maupun simultan berpengaruh signifikan terhadap keputusan pembelian pada Grace Mart Bangun Jaya.
\end{abstract}

\section{EFFECT OF SELECTION OF LAYOUT OF PRODUCTS, PRICE AND COMPLETENESS OF ITS PRODUCTS BUYING DECISIONS IN SUPERMARKETS "GRACE MART" BANGUN JAYA}

\section{Abstract}

This study aims to determine the effect of product adherence, price and completeness of the purchase decision. The sampling method used is Accidental Sampling Method. The sample in this study were 100 consumers from Grace Mart Build Jaya and then analyzed the data obtained using quantitative and qualitative data analysis. Testing the hypothesis using the $t$ test shows that the independent variables studied proved to be significantly not partially influential on the dependent variable of Purchasing Decisions. From the results of the study it can be concluded that the product layout variables, price and product completeness both partially and simultaneously have a significant effect on purchasing decisions at Grace Mart Build Jaya. Researchers suggest that companies further improve governance both in terms of product layout, price and completeness of the products provided so that more and more consumers are attracted to shopping.

$\begin{array}{lr}{ }^{\triangle} \text { Alamat korespondensi : } & \text { ISSN } \\ \text { Universitas Pasir Pengaraian } & 2684-9666 \text { (cetak) } \\ \text { Purwan78@gmail.com } & \text { 2684-8503(online) }\end{array}$




\section{PENDAHULUAN}

Setiap perusahaan dewasa ini dituntut untuk mengenal pasar atau konsumennya sebaik mungkin agar dapat sukses dalam persaingan. Ningsih (2008) mengatakan bahwa persaingan yang semakin ketat, dimana semakin banyak produsen yang terlibat dalam pemenuhan kebutuhan dan keinginan konsumen menyebabkan setiap perusahaan harus menempatkan orientasi pada konsumen sebagai tujuan utama.

Sejalan dengan pertumbuhan maka para pengusaha dituntut untuk mengelola usahanya lebih profesional dan efesien dalam menghadapi persaingan. Dengan adanya persaingan dunia usaha yang semakin tajam menuntut pula pengusaha untuk peka dan cermat didalam memilih dan menetapkan produk yang strategis dan tepat dalam penjualannya. Tata letak produk yang strategis dan tepat akan menguntungkan karena sebagian konsumen akan lebih menyukai tata letak yang bagus dan dapat dijangkau dengan mudah. Ningsih (2008) mengatakan bahwa tata letak produk yang tepat harga yang seimbang serta kelengkapan produk yang bervariasi dan lengkap secara tidak langsung akan mempengaruhi minat konsumen dalam menentukan keputusan pembelian.

Grace Mart Bangun Jaya merupakan swalayan yang menjual produk-produk yang dibutuhkan konsumen sehari-hari seperti kosmetik, peralatan mandi, perlengkapan bayi, bumbu dapur, alat-alat tulis, alat-alat listrik, makanan dan minuman, baik makanan siap saji maupun tidak. Mengenai tata letak produk, pembeli tentu akan melihat tata letak produk yang memudahkan mereka dalam mencari barang-barang yang dibutuhkan. Grace Mart Bangun Jaya salah satu penyedia barang kebutuhan pokok masyarakat, karena tata letak produk sangat berpengaruh pada keputusan pembelian. Produk-produk yang tertata rapih dan dikelompokkan sesuai dengan jenis dan merek. Dengan adanya tata letak produk yang tepat dan menarik, maka konsumen dengan sendirinya akan memutuskan minat berbelanja di Grace Mart Bangun Jaya. penatapan letak produk yang teratur dan juga konsumen tidak mesara sulit saat pembeli. Penempatan rak-rak produk ini mempunyai jarak antara satu dengan rak yang lain, agar pembeli leluasa untuk mencari barang yang dibutuhkan saat berbelanja.

Setiap pengusaha ritel memiliki kebijakan masing-masing termasuk masalah presentase harga yang diambil pada setiap produk atau barang yang dijual. Harga juga berpengaruh terhadap keputusan pembelian, harga yang terlalu mahal juga menjadi pertimbangan konsumen sebelum membeli produk, tidak jarang orang berpendapat harga di swalayan relative murah ini menjadi salah satu masalah yang dapat mempengaruhi keputusan pembelian. Dari segi harga Grace Mart Bangun Jaya cukup kompetitif dalam menentukan harga jual produk. Terlebih jika dibandingkan dengan AlfaMart dan IndoMart diwilayah Bangun Jaya, hal ini menjadi persaingan yang ketat dalam menarik konsumen. Sehingga dalam beberapa kondisi Grace Mart Bangun Jaya benar-benar menekan harga semurah mungkin. Hal ini terpaksa dilakukan pihak perusahaan untuk menghindari kerugian yang besar karena banyak produk dengan masa expirednya pendek yang menumpuk digudang.

Faktor kelengkapan produk juga nampaknya sangat berpengaruh pada konsumen ketika akan melakukan keputusan pembelian. Hal ini berkaitan dengan kepuasan konsumen dalam berbelanja. Sering kali produk yang tidak lengkap membuat konsumen merasa enggan untuk kembali berbelanja. Data kelengkapan produk yang peneliti dapat dari hasil wawancara dengan pemilik Grace Mart Bangun jaya bahwa produk yang dijual di swalayan Grace Mart Bangun Jaya sangat banyak dan lengkap 
produk dimulai dari beras, minyak sayur, gula, terigu, telur, sabun mandi, sabun cuci, macam-macam obat-obatan, minuman kemasan , makanan kemasan, kopi, susu, aneka bumbu dapur, alat tulis, macam-macam rokok, kosmetik, perlengkapan bayi, bahkan sampai alat-alat listrik. Produk-produk tersebut tersedia dalam berbagai variasi, ukuran, rasa dan juga berbagai merek. Namum ada saja produk yang dicari konsumen tidak tersedia (out of stock) karena berbagai sebab, seperti permintaan atas produk tertentu lebih tinggi dari pemikiran dan stock yang disediakan oleh swalayan pada preiode tertentu, pengiriman barang dari pemasok yang terlambat, adanya kelengkapan produk dipasaran dan lain-lain.

Dalam hal ini Grace Mart Bangun Jaya sangat memperhatikan kelengkapan produk yang ditawarkan kepada konsumen, dalam satu produk banyak berbagai variasi dan ragam produk yang dibutuhkan oleh konsumen untuk memenuhi kebutuhannya sehingga tidak membuat konsumen jera dan membuat konsumen untuk melakukan pembelian ulang. Jumlah kariyawan yang bekarja di Grace Mart Bangun Jaya sebanyak enam orang, dengan begitu ketika konsumen yang berbelanja sangat banyak konsumen tidak merasa kekurangan produk yang mereka butuhkan karena apabila produk yang dirasa sudah mulai berkurang maka kariyawan langsung mengambil barang persediaan digudang. Hal ini dapat memuaskan seluruh konsumen ketika berbelanja. Keputusan pembelian merupakan usaha konsumen untuk mengidentifikasikan semua pilihan yang mungkin untuk memecahkan persoalan dan menilai pilihanpilihan secara sistematis dan objektif serta sasaran-sasarannya yang menentukan keuntungan serta kerugian masing-masing. Pemasaran merupakan salah satu aktivitas yang dapat menentukan keberhasilan dan mencapai tujuan perusahaan. Tujuan aktivitas pemasaran untuk meningkatkan penjualan, tentunya dengan cara memenuhi kebutuhan dan keinginan konsumen. Jika mengartikan pemasaran itu sama halnya dengan penjualan, itu merupakan suatu kesalahan. Karena aktivitas pemasaran tidak hanya pada penjualan dan promosi, tetapi kegiatan pemasaran juga mengidentifikasikan pada kebutuhan dan keinginan konsumen agar bisa memuaskan konsumen.

Daryanto (2011) mengatakan pemasaran adalah suatu proses sosial dan manajerial dimana individu dan kelompok mendapatkan kebutuhan dan keinginan mereka dengan menciptakan, menawarkan, dan bertukar suatu yang bernilai satu sama lain. Anggara (2012) mengatakan bahwa tata letak produk adalah metode pengaturan dan penetapan stasiun kerja berdasarkan uru operasi dari sebuah produk.

Daryanto (2011), mengatakan harga adalah jumlah uang yang ditagihkan untuk suatu produk atau sejumlah nilai yang dipertukarkan konsumen untuk manfaatkan memiliki atau menggunakan produk. Utami (2010) mengemukakan kelengkapan produk adalah keragaman produk yang menyangkut kedalaman, luas dan kualitas produk yang ditawarkan juga ketersediaan produk tersebut setiap saat di toko. Kotler (2009), kelengkapan produk adalah ketersediaan semua jenis produk yang ditawarkan untuk dimiliki dipakai atau dikonsumsi oleh konsumen yang dihasilkan oleh suatu produsen.

Sciffman dan Kanuk (2008), megatakan Keputusan pembelian merupakan pemilihan dari dua atau lebih alternatif pilihan keputusan pembelian, artinya bahwa seseorang dapat membuat keputusan haruslah tersedia beberapa alternatif pilihan. Eta dan Sopiah (2013), mengatakan pengambilan keputusan pembelian adalah proses pengintegrasian yang mengkombinasikan pengetahuan untuk mengevaluasi dua perilaku alternatif atau lebih, dan memilih 
salah satu diantaranya. Hasil proses pengintegrasian ini adalah suatu pilihan yang disajikan secara kognitif sebagai keinginan perilaku.

\section{METODE}

Populasi dalam penelitian ini adalah seluruh konsumen yang berbelanja di Grace Mart Bangun Jaya. Jumlah sampel yang akan dipakai dalam penelitian ini adalah 100 responden dengan menggunakan metode kebetulan (accindental sampling). Data yang diperoleh dari perusahaan yang meliputi data mengenai keadaan dan jumlah karyawan, mengenai sejarah berdirinya organisasi perusahaan dan data-data lainnya yang mendukung. Tehnik Penganbilan Data Observasi, Kuesioner, Wawancara, Studi Pustaka

Metode yang dilakukan dalam penelitian ini adalah metode accidental sampling yaitu tehnik sampel berdasarkan kebetulan. Penelitian ini bersifat verifikasi dan deskriptif, penelitian bersifat verifikasi pada dasarnya ingin menguji kebanarandari hipotesis yang dilakukan melalui pengumpulan data dilapangan sedangkan deskriptif bertujuan mendeskripsi tentang variael-variabel penelitian.

Dalam pengujian akan diuji apakah ada hubungan signifikan antara variabelvariabel tersebut, sedangkan ada beberapa cara untuk mempermudah untuk melakukan penelitian, seperti: populasi dan sampel, jenis dan tehnik pengumpulan data, analisis data serta pengujian hipotesis.

\section{HASIL DAN PEMBAHASAN}

Hasil analisis validitas ditunjukan dengan membandingkan Hasil analisis validitas ditunjukan membandingkan $r_{\text {hitung }}>$ $\mathrm{r}_{\text {tabel }}$ Sedangakan nilai $\mathrm{r}_{\text {hitung }}$ dapat dilihat dalam correndet item total corelation pada program SPSS versi 16. Berdasarkan hasil uji validitas menunjukkan bahwa semua butir pertanyaan mempunyai nilai positif dan nilai tersebut adalah valid, hal ini dibuktikan dengan diperolehnya nilai koefisien korelasi $r_{\text {hitung }}>$ dari $r_{\text {tabel }}(0,1956)$. Nilai 0,1956 yang diperoleh dari nilai $r_{\text {tabel }}$ dengan $\mathrm{N}=100$ dengan signifikansi 5\% atau 0,05 (two tail).

Berdasarkan hasil Uji reabilitas dapat dijelaskan bahwa semua nilai variabel tata letak produk, harga dan kelengkapan produk menunjukkan konsistensi yang dapat di percaya atau reliabel. Hal ini memberikan kesimpulan bahwa semua butir pertanyaan yang menjadi dimensi pengukuran dari variabel yang diamati sudah reliabel.

Hasil hipotesis 1 menunjukkan bahwa variabel tata letak produk tidak memiliki pengaruh terhadap keputusan pembelian. Hal ini dibuktikan dengan nilait $_{\text {hitung }}=0,441<\mathrm{t}_{\text {tabel }}=1,66055$. Diperkuat dengan nilai signifikansi $(0,0660>0,05$ atau $5 \%$ ) artinya tidak semua variable independen berpengaruh positif dan signifikan terhadap keputusan pembelian (Y) terbukti.

Penelitian ini juga mendukung penelitian terdahulu yaitu penelitian Widodo (2016). Penelitian tersebut menemukan bahwa tata letak produk terbukti tidak memiliki pengaruh terhadap keputusan pembelian konsumen. Artinya bahwa tata letak produk merupakan salah satu variable yang hasus diperhatikan dari keputusan pembelian konsumen khususnya keputusan pembelian konsumen untuk berbelanja di Grace Mart Bangun Jaya.

Hasil hipotesis 2 menunjukkan bahwa variabel harga tidak memiliki pengaruh terhadap keputusan pembelian. Hal ini dibuktikan dengan nilait ${ }_{\text {hitung }}=1,066<$ $t_{\text {tabel }}=1,66055$. Diperkuat dengan nilai signifikansi $(0,660>0,05$ atau $5 \%)$ artinya variabel harga memiliki pengaruh yang positif dan tetapi tidak signifikan terhadap keputusan pembelian (Y) terbukti. Variabel harga dalam penelitian ini diukur dengan menggunakan indikator tingkat harga dan 
potongan harga.Penelitian ini juga mendukung penelitian terdahulu yaitu penelitian Widodo (2016), Vihda H.a (2017) dan Lesmana (2017). Penelitian tersebut sama-sama menemukan bahwa harga terbukti tidak memiliki pengaruh secara signifikan terhadap keputusan pembelian konsumen.

Hasil hipotesis 3 menunjukkan bahwa variabel kelengkapan produk memiliki pengaruh terhadap keputusan pembelian. Hal ini dibuktikan dengan nilai $\mathrm{t}_{\text {hitung }}=5,256>\mathrm{t}_{\text {tabel }}=1,66055$. Diperkuat dengan nilai signifikansi $(0,000<0,05$ atau $5 \%)$ artinya semua variable independen berpengaruh positif dan signifikan terhadap keputusan pembelian (Y) terbukti.

Penelitian ini juga mendukung penelitian terdahulu yaitu penelitian Widodo (2016). Penelitian tersebut menemukan bahwa strategi kelengkapan produk terbukti memiliki pengaruh terhadap keputusan pembelian konsumen. Hal ini mengindikasikan bahwa kelengkapan produk merupakan salah satu variabel penting atau prediktor dari keputusan pembelian konsumen khususnya keputusan pembelian konsumen untuk berbelanja di Grace Bangun Jaya.

Hasil hipotesis 4 menunjukkan bahwa variabel tata letak produk, harga dan kelengkapan produk memiliki pengaruh secara simultan terhadap keputusan pembelian. Hal ini menunjukkan bahwa tata letak produk, harga dan kelengkapan produk yang baik akan mendorong keputusan konsumen untuk berbelanja. Terlihat dari nilai $F_{\text {hitung }}=14,076>F_{\text {tabel }}=2,70$. Diperkuat dengan nilai signifikansi $(0,000<0,05$ atau $5 \%$ ) artinya semua variable independen berpengaruh positif dan signifikan terhadap keputusan pembelian (Y) terbukti.

\section{KESIMPULAN}

Dari hasil penelitian yang telah dilakukan dapat ditarik beberapa kesimpulan sebagai berikut, Responden dalam melakukan keputusan pembelian di Grace Mart bangun Jaya terbukti dipengaruhi oleh variabel tata letak produk meliputi informasi tentang produk, karyawan mengetahui macam-macam produk, swalayan memberi label pada setiap produk, memberi jaminan atas produknya, memperhatikan penempatan produk, menempatkan letak produk yang sejenis pada rak-rak produknya. Responden dalam melakukan keputusan pembelian di Grace Mart Bangun Jaya terbukti dipengaruhi oleh variabel harga yang meliputi tingkat harga dan potongan harga.

Responden dalam melakukan keputusan pembelian di Grace Mart Bangun Jaya terbukti dipengaruhi oleh variabel kelengkapan produk yang meliputi keragaman produk yang dijual, menyediakan produk yang komplit ukuran yang besar hingga yang kecil, memiliki variasi produk yang lengkap, kelengkapan ukuran produk dari yang besar hingga yang kecil, ketersediaan ukuran produk, menjaga ketersediaan produk, ketersediaan produk selalu ada saat dicari, ketersediaan produk memberikan daya tarik bagi konsumen, menyediakan bermacam merek, merek produk yang disediakan memberikan kenyamanan dalam memilih.

Responden dalam melakukan keputusan pembelian di Grace Mart Bangun Jaya terbukti dipengaruhi oleh variabel pemilihan tata letak produk, harga dan kelengkapan produk.

\section{SARAN}

Adapun saran-saran yang diberikan, Bagi perusahaan Grace Mart Bangun Jaya, peneliti menyarankan untuk tetap mempertahankan menetapkan harga yang sesuai terhadap kualitas produk yang dijualnya. Harga produk sebaiknya sesuai fitur yang ditawarkan dan bersaing. Selain itu Grace Mart Bangun Jaya lebih memperhatikan dan meningkatkan penataan tata letak produk agar konsumen kembali berbelanja di Grace Mart Bangu Jaya , selain itu Grace Mart bangun Jaya juga mempertahankan kelengkapan produk yang sudah ada agar konsumen lebih nyaman saat bebelanja karena produk yang disediakan sudah lengkap. Bagi peneliti lain, disarankan sebaiknya menambah variabel baru sebagai variabel independen sehingga dapat memperluas lingkup penelitian. Penambahan sampel sangat disarankan agar hasil penelitian dapat lebih akurat. 


\section{DAFTAR PUSTAKA}

Anoname. Harga. Wikipedia bahasa Indonesia. Ensiklopedia bebas.http:/id.m.wikipedia.org/wiki/Harga. diakses pada Tanggal 15 September 2018 pukil 16. 15

Arianti, 2016. Pengaruh Harga, Kelengkapan Produk, dan Display Produk Terhadap Keputusan Pembelian Ulang Konsumen Mitra Karanganyar. Universitas Muhammadiyah : Surakarta.

Assauri, Sofjan. 2010. Manajemen Pemasaran. Rajawali Pres : Jakarta.

Daryanto. 2011. Sari Kuliah Manajemen Pemasaran. Satu Nusa : Bandung.

Dedy Hidayat. 2016. Analisis Pengaruh Kualitas Pelayanan, Harga dan kelengkapan Produk Terhadap Keputusan Pembelian Pengunjung Gembira Loka. Universitas PGRI yogyakarta: Yogyakarta.

Diah Suryaningsih. 2008. Pengaruh Tata Letak Produk dan Kualitas Pelayanan Terhadap Kepuasan Konsumen Pada Assalaam Hypermarket. Universitas Muhammadiah Surakarta: Surakarta.

Eva Zhoriva Yusuf dan L. Wiliams. 2007. Manajemen Pemasaran/Studi Kasus Indonesia. PPM : Jakarta.

Elanita, Wililya. 2016. Pengaruh Pemilihan Lokasi, Harga, dan Pelayanan Tarhadap Keputusan Pembelian Pada Ilham Mart Pasir pengaraian.Universitas Pasir Pengaraian, Pasir Pengaraian.

Ferdi Setiawan. 2009. Analisis Penetapan Tata Letak Produk dan Strategi Penjualan Dengan Metode Market Basket pada Ritel Hypermaeket. Universitas Indonesia : jakarta.

Gilbert, david. 2003. Retail Marketing manajemen. New Jersey: PranticelHall.

Hafiza Alreza Anan. 2013. Pengaruh Kelengkapan Produk dan Pelayanan Terhadap Keputusan Pembelian Pada Swalayan Bravo Di Kota Bojonegoro. Universitas Nergi Semarang: Semarang.

Jay Heizer dan Barry Render. 2006. Manajemen Oprasi. Penerbit Selemba Empat : Jakarta.

Kismono, Gugup. 2001. Pengantar Bisnis. Yogyakarta: BPEE.

Kotler, Philip. 2002. Marketing Manajement. New Jersey. The Millenium Edition, PrenticelHall International Edition.

Kotler, Philip dan Keller, Lane. 2007. Manajemen Pemasaran. Penerbit Erlangga: Jakarta

Kotler, Philip dan Amstrong, Gary. 2008. PrinsipPrinsip Pemasaran. Penerbit Erlangga: Jakarta
Kotler, Philip dan Keller, Lane. 2009. Manajemen Pemasaran. Penerbit Erlangga: Jakarta.

Ma'ruf, Hendri. 2005. Pemasaran Ritel. Jakarta: Gramedia Media Pustaka Utama

Made Agung Nugraha, Ni Nyoman Yulianthini, dan Gede Putu Agus jana susila. 2016. eJurnal Bisma. Pengaruh Harga, Kualitas Pelayanan dan Promosi Terhadap Penjualan. Universitas Pendidikan Ganesha Singaraja: Indonesia.

M. Mursid. 2014. Manajemen Pemasaran. Bumi Aksara: Jakarta.

Raharjani,Jeni. 2005 Analisis Faktor-faktor yang Mempengaruhi Keputusan Konsumen Swalayan sebagai tempat Berbelanja. Studi Kasus pada Pasar Swalayan di Kawasan Seputar Simpang Lima Semarang. Dalam Jurnal Studi Manajemen \& Organisasi,Vol 2 No.1 Hal 1-15.

Riduwan, Akdon. 2010. Rumus dan Data dalam Analisin Statistika. Penerbit Alfabeta: Bandung.

Rosa Lemana. 2017. Jurnal Pemasaran Kompetitif. Pengaruh Kelengkapan Produk dan Penetapan Harga Terhadap Keputusan Pembelian konsumen studi Kasus pada Toko H. Cisauk Tanggerang.

Sugiyono. 2008. Metode Penelitian Kuantitatif Kualitatif dan $R \& D$. Penerbit Alfabeta : Bandung

Sugiyono. 2010. Metode Penelitian Kuantitatif Kualitatif dan $R \& D$. Penerbit Alfabeta : Bandung.

Sugiyono. 2012. Metode Penelitian Kuantitatif Kualitatif dan $R \& D$. Penerbit Alfabeta : Bandung.

Sukri. 2015. Faktor-faktor yang Mempengaruhi Minat Beli Konsumen pada CV. Master Pasir Pengaraian Kabupaten Rokan Hulu. Universitas Pasir Pengaraian.

Sunyoto, Danang. 2013. Perilaku Konsumen. CAPS; Yogyakarta

Swastha, Basu DH. 2006. Strategi Pemasaran. Penerbit BFEE; Yogyakarta.

Tanjung, Vina. 2013. Kualitas Produk, Strategi Harga dan Minat Beli Konsumen.http;/bloggerviens.blogspot.co.id.2013/01/kualitasproduk.html?,=1. Diakses pada tanggal 15 September Pukul 19.05

Thamrin Abdullah dan Franchis Tantri. 2013. Manajemen Pemasaran. Rajawali Pres : Jakarta

Tjiptono, Fandy. 2006. Pemasaran Jasa. Bayumedia Publising: Malang.

Tjiptono, Fandy. 2010. Strategi Pemasaran. Penerbit Andi: Yogyakatra. 
Tri Widodo, 2016. Pengaruh Kelengkapan Produk Dan Pelayanan Terhadap Keputusan Pembelian Pada Swalayan Ada Baru Di Kota Salatiga. Dosen Tetap STIE AMA Salatiga

Vidha Harra Afifah. 2017. Pengaruh Kualitas Pelayanan, Harga dan Kelengkapan Barang Terhadap Keputusan Pembelian
Pada Apotek Farma. Akademi Akuntansi Permata Harapan Batam: Batam.

Widianto, Ibnu. 2008. Pointers: Metodologi Penelitian. Penerbit Universitas Dipenogoro: Semarang

Zulkarnain. 2012. Ilmi Menjual, Pendekatan Teoritis dan Kecakapan Menjual. Graha Ilmu: Yogyakarta. 